\title{
Clinico-immunological profile and outcome of childhood systemic lupus erythematosus
}

\author{
Ramya Kadiyala ${ }^{1}$, *Pushpa Gurudas Kini ${ }^{1}$, Shrikiran Aroor ${ }^{1}$, Sandeep Kumar $^{1}$, Karen Moras ${ }^{1}$
}

Sri Lanka Journal of Child of Child Health, 2019; 48(3): 201-207

\begin{abstract}
Introduction: Paediatric lupus is an autoimmune disorder most commonly affecting adolescent females. Various studies regarding paediatric lupus have been reported across the world.
\end{abstract}

Objective: To study the clinical and immunological features of systemic lupus erythematosus (SLE) along with treatment modalities and the response at the end of one year follow up. Relationship between the types of autoantibodies and probability of systemic involvement is also assessed.

Method: A prospective and retrospective observational study was carried out in the Paediatric Department of a tertiary care hospital from January 2010 to July 2016. Subjects included children from 1 month to 18 years of age fulfilling the 1997 American College of Rheumatology criteria for SLE.

Results: Study population included 44 children fulfilling the criteria. Among them 10 were in the prospective group and 34 in the retrospective group. Female: male ratio was 4.5:1. Median age at diagnosis was 13.2 years (interquartile range 11.214.6). Presenting features were constitutional in $86.4 \%$, musculoskeletal in $72.7 \%$, renal in $65.9 \%$, haematological in $63.6 \%$, muco-cutaneous in $61.3 \%$, central nervous system in $36.3 \%$ and serositis in $25 \%$ children. Anaemia was the commonest haematological abnormality and was found in $75 \%$ of children. Hypocomplementaemia was seen in $100 \%$ of children. All subjects were positive for antinuclear antibodies. Anti-double stranded DNA (77.2\%) was the most commonly observed autoantibody profile followed by antiribosomal P protein $(47.7 \%)$ and antiribonucleoprotein (43.1\%). During follow up of 36

\footnotetext{
${ }^{1}$ Kasturba Medical College Manipal, India

*Correspondence: kini.pushpa@gmail.com

iD,

orcid.org/ 0000-0001-6186-0336
}

(Received on 27 July 2018: Accepted after revision on 28 September 2018)

The authors declare that there are no conflicts of interest

Personal funding was used for the project.

Open Access Article published under the Creative

Commons Attribution CC-BY (c) (P) children, $19(52.7 \%)$ children attained complete remission, $8(22.3 \%)$ went into partial remission and $9(25 \%)$ had persisting active disease. During the study period $13(29.5 \%)$ of 44 children succumbed either to the active disease process or to complication of SLE.

Conclusions: The clinical presentation and course of progression of the disease varies depending on the age of onset and the organ system involved. Low complement levels indicate activation of the disease especially lupus nephritis.

DOI: http://dx.doi.org/10.4038/sljch.v48i3.8753

(Key words: Paediatric lupus, lupus nephritis, immuno-suppressants, children)

\section{Introduction}

Systemic lupus erythematosus (SLE) is characterized by multi-organ inflammation with autoantibody production and the course of the disease is marked by periods of flare and remission leading to irreversible tissue damage and premature death $^{1}$. Peak incidence is around 10-14 years with female predominance, gender ratio of male: female being $3: 4$ before puberty and 1:4 after puberty ${ }^{2}$. SLE is rare in children under 5 years of age and has a higher risk of morbidity and mortality compared to adults $^{3}$. Age at onset of disease and duration of symptoms prior to diagnosis are known to have a modifying effect on disease expression ${ }^{4}$. The clinical manifestations of SLE vary from mild fever, erythematous rash, polyarthralgia, arthritis, polyserositis, anaemia and thrombocytopenia to renal and neurological involvement ${ }^{5,6}$. Organs are involved more in children than adults ${ }^{4-6}$.

\section{Objectives}

To study the clinical and immunological features of SLE along with treatment modalities and the response at the end of 1 year follow up. Relationship between the types of autoantibodies and probability of systemic involvement was also assessed.

\section{Method}

A prospective and retrospective observational study was carried out in the Paediatric Department of a tertiary care hospital from January 2010 to July 2016. The study population included children from 1 month to 18 years of age admitted with SLE. Written informed parental consent was obtained 
prior to commencement of the study. Children were included in the study if they fulfilled 4 of the 1997 American College of Rheumatology (ACR) criteria for SLE, including 1 clinical and 1 immunologic criterion or in the presence of biopsy-proven lupus nephritis with positive antinuclear antibody (ANA) profile or anti-double stranded deoxyribonucleic acid (dsDNA) antibodies. Children who were lost to follow-up within one year following the diagnosis were excluded from the study. Ethical approval was obtained from the Institutional Ethics Committee (IEC-636/2015). Demographic data, symptomatology and investigations in retrospective cases were obtained by perusing medical records.

Lupus nephritis (LN) was considered if child had hypertension (systolic or diastolic blood pressure more than $95^{\text {th }}$ centile for age and sex), abnormalities in urine analysis or raised serum creatinine as per age specific limit. Hypocomplementaemia was defined in accordance with age specific normal complement values. Renal biopsy was done if there was evidence of LN clinically and lesions were categorized using the World Health Organization classification criteria. Investigations like haemogram, erythrocyte sedimentation rate, Creactive protein, serum creatinine, Coombs test, ANA profile, complement level, urine routine and a 24 hour quantification of urine protein were done at the first visit and when indicated during follow up. At the end of 1 year follow up outcome was defined in 4 categories i.e. complete remission, partial remission, presence of active disease and expired.

Clinical remission was defined as at least 6 months absence of disease activity clinically either on or off treatment ${ }^{7}$. Laboratory remission was defined as the time taken for indicators of active disease like C3 complement, proteinuria and hypertension to normalize either on or off treatment ${ }^{7,8}$. Complete remission was considered when proteinuria was $<4 \mathrm{mg} / \mathrm{m}^{2} / \mathrm{hr}$, urine analysis showed $1+/$ nil protein, there were less than 5 red blood cells (RBCs) and or less than 5 white blood cells (WBCs), no cellular casts, no evidence of extra-renal manifestations and normo-complementaemia. Partial remission was considered when proteinuria was 4 to $40 \mathrm{mg} / \mathrm{m}^{2} / \mathrm{hr}$ or was reduced by at least $50 \%$ from baseline and there were $<5 \mathrm{RBCs},<5 \mathrm{WBCs}$ and no cellular casts. Active disease was said to persist when proteinuria was $>40 \mathrm{mg} / \mathrm{m}^{2} / \mathrm{hr}$ or between 4 to $40 \mathrm{mg} / \mathrm{m}^{2} / \mathrm{hr}$ with a reduction of less than $50 \%$ from baseline or presence of active sediment or extra-renal manifestations. Measurable worsening of disease activity in the form of new or worse disease related symptoms or signs in at least 1 organ system requiring change or increase in immunosuppressive treatment was considered as a disease flare ${ }^{8}$.

Data were analysed using SPSS version 21. Descriptive data was expressed as percentage, median and interquartile range. Chi-square was used for categorical variables. Mann-Whitney test was used to analyse of continuous variables. $p<0.05$ was taken as statistically significant.

\section{Results}

There were 53 children with SLE during the study period. However, 44 children comprised the study group as 9 were lost for follow up. Among these 10 belonged to the prospective group and 34 children were in the retrospective group (Figure 1).

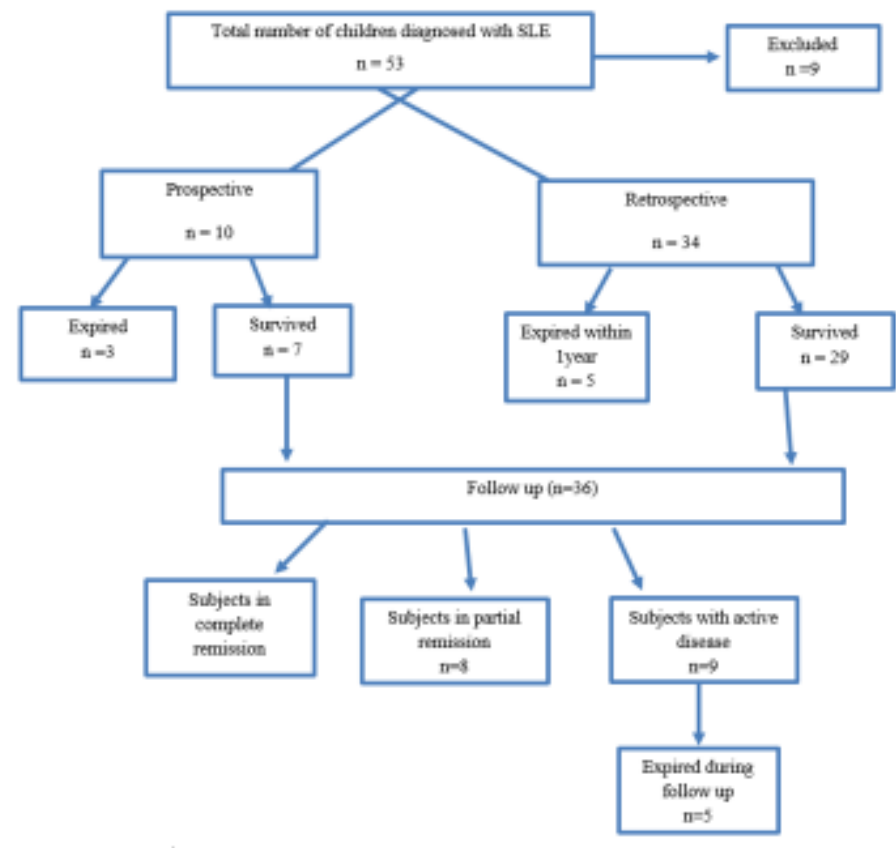

Figure 1: Temporal profile of study subjects 
Study population included 36 females and 8 males with a female: male ratio of 4.5:1. Median age at diagnosis was 13.2 years (interquartile range [IQR] 11.2-14.6) with the earliest presentation at the age of 2.8 years. Children in the age group of 7-14 years $(56.8 \%)$ were most commonly affected (Table 1$)$.

The clinical presentation of SLE varied in different subjects. The median duration of symptoms at the time of diagnosis was 60 days (IQR 20-120). Constitutional symptoms like fever, weight loss and fatigue were present in 38 (86.4\%) children. Musculoskeletal manifestations were most commonly observed $(72.7 \%)$, followed by renal $(65.9 \%)$, haematological $(63.6 \%)$, muco-cutaneous $(61.3 \%)$, central nervous system $(36.3 \%)$ and serositis $(25 \%)$. (Table 2$)$.
Table 1

Demographic data of the study population $(n=44)$

\begin{tabular}{|l|c|}
\hline \multicolumn{1}{|c|}{ Parameter } & Number (\%) \\
\hline Age at diagnosis ( years) & \\
$<7$ & $04(09.0)$ \\
$7-14$ & $25(56.8)$ \\
$>14$ & $15(34.0)$ \\
\hline Gender & \\
Female & $36(81.8)$ \\
Male & $08(18.1)$ \\
\hline$B M I<3^{\text {rd }}$ Centile & $20(45.4)$ \\
\hline
\end{tabular}

BMI: Body mass index

Table 2: Clinico-laboratory features of children with SLE at admission (n=44)

\begin{tabular}{|c|c|}
\hline Clinico-haematologic parameter & Number (\%) \\
\hline Constitutional symptoms & $38(86.4)$ \\
\hline Fever & $26(59.0)$ \\
\hline Weight loss & $11(25.0)$ \\
\hline Fatigue & $08(18.0)$ \\
\hline Muco-cutaneous & $27(61.3)$ \\
\hline Malar rash & $19(43.1)$ \\
\hline Alopecia & $15(34.0)$ \\
\hline Photosensitivity & $14(31.8)$ \\
\hline Oral ulcer & $13(29.5)$ \\
\hline Raynaud's phenomenon & $02(04.5)$ \\
\hline Musculoskeletal & $32(72.7)$ \\
\hline Arthralgia & $28(63.6)$ \\
\hline Arthritis & $15(34.0)$ \\
\hline Myalgia & $11(25.0)$ \\
\hline Serositis & $11(25.0)$ \\
\hline Pericardial effusion & $07(15.9)$ \\
\hline Pleural effusion & $06(13.6)$ \\
\hline Ascites & $05(11.3)$ \\
\hline Peritonitis & $01(02.2)$ \\
\hline Nervous System involvement & $17(38.6)$ \\
\hline Seizures & $05(11.3)$ \\
\hline Hemiparesis & $04(09.0)$ \\
\hline Vasculitis & $04(09.0)$ \\
\hline Psychosis & $03(06.8)$ \\
\hline Depression & $01(02.2)$ \\
\hline Peripheral neuropathy & $01(02.2)$ \\
\hline Renal & $30(68.1)$ \\
\hline \multicolumn{2}{|l|}{ Laboratory parameters } \\
\hline Anaemia & $36(81.8)$ \\
\hline Lymphopenia & $33(75.0)$ \\
\hline Thrombocytopenia & $18(40.9)$ \\
\hline Leucopenia & $15(34.0)$ \\
\hline Prolonged APTT & 07 (15.9) \\
\hline Autoimmune hemolytic anemia & $06(13.6)$ \\
\hline Elevated ESR & $05(11.3)$ \\
\hline \multicolumn{2}{|l|}{ Hypocomplementaemia } \\
\hline Low C3 & $44(100.0)$ \\
\hline Low C4 & $38(86.4)$ \\
\hline
\end{tabular}


Proteinuria was the most common renal manifestation and was observed in $68.1 \%$ of children. Among 39 children in whom 24 hour quantification of proteinuria was done, $41 \%$ had nephrotic range proteinuria, $36 \%$ had non nephrotic range proteinuria and $23 \%$ had proteinuria $<4 \mathrm{mg} / \mathrm{m}^{2} / \mathrm{hr}$. The median value of timed urine protein was $31 \mathrm{mg} / \mathrm{m}^{2} / \mathrm{hr}$. Gross haematuria was seen in $13.6 \%$ children while microscopic haematuria was observed in 50\%. Hypertension was noticed in $40.9 \%$ of children while deranged renal function was observed in $25 \%$. Anaemia was observed in $75 \%$ children of whom $11.3 \%$ had autoimmune haemolytic anaemia. Leucopenia was seen in 15.9\% children of which lymphopenia accounted for
40.9\%. Hypocomplementaemia and elevated ESR were observed in all children with a median C3 of $38 \mathrm{mg} / \mathrm{dl}$ and a median ESR of $75 \mathrm{~mm} / \mathrm{hr}$.

All the subjects in this study were positive for antinuclear antibodies (ANA). Anti-dsDNA was the most commonly $(77.2 \%)$ observed positive autoantibody profile followed by anti-ribosomal $\mathrm{P}$ protein (RibP) (47.7\%) and ribonucleoprotein (RNP) (43.1\%). Anti-ds DNA positivity was associated with $\mathrm{LN}$ with a $\mathrm{p}$ value of 0.04 . Similarly there was significant association of neuropsychiatric lupus (NPL) with RibP \& RNP positivity ( $p$ values of 0.02 and 0.002 respectively) (Table 3 ).

Table 3: Spectrum of systemic involvement in relation to the immunological profile

\begin{tabular}{|l|c|c|c|c|c|c|c|}
\hline \multirow{2}{*}{ Clinical Spectrum } & \multicolumn{9}{|c|}{ Immunological Profile } \\
\cline { 2 - 8 } & $\begin{array}{c}\text { Anti-ds DNA } \\
\mathrm{n}=34\end{array}$ & $\begin{array}{c}\text { Anti-RNP } \\
\mathrm{n}=19\end{array}$ & $\begin{array}{c}\text { Anti-Smith } \\
\mathrm{n}=15\end{array}$ & $\begin{array}{c}\text { Anti-Rib P } \\
\mathrm{n}=21\end{array}$ & $\begin{array}{c}\text { Anti-Ro/La } \\
\mathrm{n}=13\end{array}$ & $\begin{array}{c}\text { Anti- } \\
\text { Nucleosome } \\
\mathrm{n}=11\end{array}$ & $\begin{array}{c}\text { Anti- } \\
\text { histone } \\
\mathrm{n}=17\end{array}$ \\
\hline $\begin{array}{l}\text { Lupus Nephritis } \\
\mathrm{n}=29 \\
\mathrm{P} \text { value }\end{array}$ & 25 & 11 & 08 & 12 & 09 & 13 & 07 \\
\hline $\begin{array}{l}\text { Neuro-psychiatric lupus } \\
\mathrm{n}=16\end{array}$ & $\mathbf{( 0 . 0 4 )}$ & $(0.2)$ & $(0.14)$ & $(0.15)$ & $(0.86)$ & $(0.4)$ & $(0.3)$ \\
P value & 12 & 12 & 08 & 09 & 05 & 04 & 08 \\
\hline $\begin{array}{l}\text { Serositis } \\
\mathrm{n}=11\end{array}$ & $(0.7)$ & $\mathbf{( 0 . 0 0 2})$ & $(0.1)$ & $\mathbf{( 0 . 0 2}$ & $(0.7)$ & $(0.2)$ & $(0.5)$ \\
P value & 09 & 05 & 03 & 07 & 03 & 09 & 05 \\
$\begin{array}{l}\text { Hematological } \\
\mathrm{n}=28 \\
\text { P value }\end{array}$ & $(0.8)$ & $(0.9)$ & $(0.5)$ & $(0.2)$ & $(0.8)$ & $(0.1)$ & $(0.08)$ \\
\hline
\end{tabular}

Class IV $(50 \%)$ was the most common histopathological category in renal biopsy in children with LN followed by class II (24\%), class III $(16 \%)$ and class V $(10 \%)$. Children with proliferative $\mathrm{LN}$ had bad outcome in terms of remission, death and response to immunosuppressive therapy.

Steroids were the mainstay of treatment for systemic manifestations of SLE. Additional immunosuppressants or immuno-modulators were used in children as required (Table 4).

Table 4

Treatment modalities in children with SLE $(n=44)$

\begin{tabular}{|l|c|}
\hline \multicolumn{1}{|c|}{ Treatment } & Number (\%) \\
\hline Steroid & $44(100.0)$ \\
\hline Hydroxychloroquine & $30(68.0)$ \\
\hline NSAID & $16(36.3)$ \\
\hline Azathioprine & $13(29.5)$ \\
\hline Cyclophosphamide & $12(27.2)$ \\
\hline Mycophenolate mofetil & $09(20.4)$ \\
\hline Methotrexate & $06(13.6)$ \\
\hline Cyclosporine & $01(02.2)$ \\
\hline
\end{tabular}

NSAID: Non-steroidal anti-inflammatory drugs

The decision to optimize the dose of steroids or addition of immunosuppressive during follow up was based on clinical symptomatology and laboratory investigations especially ESR and C3 levels. Immunosuppressants were used in children with Class III LP and above. Cyclophosphamide and hydroxychloroquine were used mainly in class III LP, while azathioprine, cyclophosphamide and mycophenolate mofetil (MMF) were used in class IV and class V LP. There was good response to MMF where 6 of the 8 children attained remission.

The median duration of follow up from the time of diagnosis was 30 months (IQR 14-48). At the end of 1 year follow up of 36 children, $19(52.7 \%)$ children attained complete remission, $8(22.3 \%)$ went into partial remission and $9(25 \%)$ had persisting active disease. During the study period 13 of 44 children $(29.5 \%)$ succumbed either due to active disease process or complication of SLE. Fifteen of 22 children $(55.5 \%)$ were noticed to have flares after achieving remission during their follow up period. The median duration of clinical and laboratory remission were 3 months (IQR 6, 2) and 5.5 months (IQR 16.7, 2) respectively.

\section{Discussion}

There is a higher incidence of SLE in Asian populations ${ }^{9}$. Although SLE is more common in adolescent females, it may be seen in $10-15 \%$ of children younger than 16 years $^{2,10}$. In the present 
study, the common age groups were 7-14 years $(56.8 \%)$ and $>14$ years $(34 \%)$. Studies have shown that the age at onset of SLE determines its expression pattern ${ }^{10}$. Serious manifestations like renal and CNS involvement are more common in children $^{11}$. Fessel et al reported that the peak incidence of Juvenile SLE is around puberty and that it is rare in children less than 5 years of age ${ }^{12}$. In the present study, the median age at diagnosis was 13.2 years. Youngest age of presentation was 3 years. Pradhan et al reported a male: female ratio of approximately 1:4 occurring before puberty and 1:8 thereafter ${ }^{5}$. In our study, ratio of male to female was 1:4.4. In our study, commonly observed manifestations were musculoskeletal $(72.7 \%)$, renal $(65.9 \%)$, haematological $(63.6 \%)$, mucocutaneous $(61.3 \%)$, and constitutional symptoms (59\%). There were similar findings in studies by Cabral et $\mathrm{al}^{13}$ and Shrivasthav et $\mathrm{al}^{14}$.

Definitive diagnosis of $\mathrm{LN}$ is based on the immunofluorescence (IF) pattern on renal biopsy ${ }^{15-}$ 17. Keisha $\mathrm{L}$ et al reported that $\mathrm{LN}$ is seen in 20 to $80 \%$ of children with SLE and in 10 to $50 \%$ of them it progressed to end stage renal disease (ESRD) ${ }^{18}$. In our study, renal involvement was seen in $65.9 \%$ of children and proteinuria was the most common renal manifestation (68.1\%). Brugos et al showed that children with classes II and V on renal biopsy have better prognoses than children in classes III and IV who are more likely to progress to $\mathrm{ESRD}^{19}$. In our study, Class IV LN (40\%) was the commonest histology on renal biopsy. Using aggressive therapy ESRD frequency has decreased to $10-20 \% 10$ years after diagnosis ${ }^{20,21}$.

Cytopenias are common in SLE, at least 50\% children manifesting it in at least one cell line ${ }^{22,23}$. Leucopenia is the most common haematological manifestation, lymphopenia being seen more frequently than neutropenia. Persistent lymphopenia is usually observed in active disease but it is also seen in those on treatment with immunosuppressants. Anaemia can be normocytic normochromic, microcytic hypochromic or haemolytic. In our study about three fourths of the subjects had anaemia with a median haemoglobin $(\mathrm{Hb})$ of $8.9 \mathrm{~g} / \mathrm{dl}$. Autoimmune haemolytic anaemia was seen in $11.3 \%$ of children. Leucopenia was seen in $15.9 \%$ children with a median total count of 5900 cells/cu mm. Lymphopenia was seen in $40.9 \%$ children with a median absolute lymphocyte count of $1716 / \mathrm{cu} \mathrm{mm}$. In a study done by Fonta et al, the mean $\mathrm{Hb}$ was $10.2 \mathrm{~g} / \mathrm{dl}$, with a median total count of $3794 / \mathrm{cu} \mathrm{mm}$ and an absolute lymphocyte count of $1037 / \mathrm{cu} \mathrm{mm}^{4}$.

Definitive laboratory workup has to be done in those children whose clinical signs and symptoms match the diagnostic criteria. ANA positivity is the definitive criterion for diagnosis of SLE. All the children in the present study had ANA positivity. Recognizing the subtype of autoantibodies by ANA profile is a valid investigation as the presence of a particular autoantibody correlates with the characteristic organ system involvement ${ }^{23}$. ANA as a diagnostic tool for SLE has a sensitivity $>95 \%$ but has less specificity ${ }^{24}$. In our study, ds DNA positivity was associated with nephritis $(\mathrm{p}=0.04)$ and RibP \& RNP were associated with neuropsychiatric lupus (NLP) with $p$ values of 0.02 and 0.002 respectively. Other immunological features of SLE include hypocomplementaemia either $\mathrm{C} 3$ and/or $\mathrm{C} 4$. In our study, hypocomplementaemia and elevated ESR were observed in all children with a median C3 of $38 \mathrm{mg} / \mathrm{dl}$ and a median ESR of $75 \mathrm{~mm} / \mathrm{hr}$. In a study by Fonta et al, mean ESR was $74 \mathrm{~mm} / \mathrm{hr}$ with a mean $\mathrm{C} 3$ of $67.9 \mathrm{mg} / \mathrm{dl}^{4}$.

The management of SLE is aimed at attaining and maintaining remission as well as managing an episode of disease flare. Steroids are the cornerstone of pharmacotherapy in children with SLE with or without major systemic involvement. Dose adjustment is done based on the response as assessed by improving clinical signs, symptoms and laboratory investigations ${ }^{24-25}$. High ESR and low C3 levels correlated well with the symptomatology of clinical flare. In those who were asymptomatic, the drug dose modification was done so as to achieve normo-complementaemia. Immunosuppressive drugs are used as steroid sparing agents and improve prognosis for patients with renal and CNS involvement. In the present study, steroids were used in all children, hydroxychloroquine was used in 26 (68.4\%), cyclophosphamide in 12 (31.5\%), mycophenolate mofetil in $8(21 \%)$ and azathioprine in $11(28.9 \%)$ as per indication.

In the present study, at the end of 1 year of follow up of 36 children, $19(52.7 \%)$ were in complete remission, $8(22.3 \%)$ in partial remission and 9 $(25 \%)$ had persistence of active disease. The total number of children who succumbed during the study was $13(29.5 \%), 8$ children dying before 1 year of follow up and 5 children dying during the follow up period.

\section{Conclusions}

The clinical presentation and course of progression of the disease varies depending on the age of onset and the organ system involved. Low complement levels indicate activation of the disease especially lupus nephritis.

\section{References}

1. Silverman E, Eddy A. Systemic Lupus Erythematosus In: Cassidy JT, Petty RE, Laxer RM, Lindsley CB editors. Textbook 
of Pediatric Rheumatology 7th ed. Philadelphia: Elsevier Saunders; 2011. p. 285-315.

https://doi.org/10.1016/B978-1-4160-

6581-4.10021-4

2. Bastug F, Poyrazoglu H, Gunduz Z, Tulpar S, Dusunsel R. Juvenile Lupus Erythematosus: Fourteen Years of Experience. Turkish Journal of Rheumatology 2011; 26(4):308-15. https://doi.org/10.5606/tjr.2011.049

3. Fessel WJ. Epidemiology of systemic lupus erythematosus. Rheumatic Diseases Clinics of North America 1988; 14(1); 1523.

PMid: 3041487

4. Font J, Cervera R, Espinosa G, Pallares L, Ramos-Casals $\mathrm{M}$, Jimenez $\mathrm{S}$, et al. Systemic lupus erythematosus (SLE) in childhood: analysis of clinical and immunological findings in 34 patients and comparison with SLE characteristics in adults. Annals of the Rheumatic Diseases 1998; 57(8): 456-9.

https://doi.org/10.1136/ard.57.8.456

PMid: 9797549 PMCid: PMC1752720

5. Pradhan V, Patwardhan M, Rajadhyaksha A, Ghosh K. Clinical and immunological profile of systemic lupus erythematosus. Indian Pediatrics 2013; 50(4):405-7. https://doi.org/10.1007/s13312-013-0115z

PMid: 23024105

6. Ferraz MB, Goldenberg J, Hilario MO, Bastos WA, Oliveira SK, Azevedo EC, et al. Evaluation of the 1982 ARA lupus criteria data set in paediatric patients. Committees of Pediatric Rheumatology of the Brazilian Society of Pediatrics and the Brazilian Society of Rheumatology. Clinical and Experimental Rheumatology1994; 12(1):83-7.

PMid: 7741825

7. Moser KL, Kelly JA, Lessard CJ, Harley JB. Recent insights into the genetic basis of systemic lupus erythematosus. Genes and Immunity 2009; 10(5):373-9.

https://doi.org/10.1038/gene.2009.39

PMid: 19440199 PMCid: PMC3144759

8. Tsokos GC, Kammer GM. Molecular aberrations in human systemic lupus erythematosus. Molecular Medicine Today 2000; 6(11):418-24.
https://doi.org/10.1016/S13574310(00)017 98-6

9. Tavangar-Rad F, Ziaee V, Moradinejad M$\mathrm{H}$, Tahghighi F. Morbidity and mortality in Iranian children with Juvenile Systemic Lupus erythematosus. Iranian Journal in Pediatrics 2014; 24 (4): 365-70.

PMid: 25755856 PMCid: PMC4339558

10. Lehman TJ, McCurdy DK, Bernstein BH, King KK, Hanson V. Systemic lupus erythematosus in the first decade of life. Pediatrics. 1989; 83(2):235-9. PMid: 2913553

11. Watson L, Leone V, Pilkington C, Tullus $\mathrm{K}$, Rangaraj S, McDonagh JE, et al. Disease activity, severity, and damage in the UK Juvenile-Onset Systemic Lupus Erythematosus Cohort. Arthritis and Rheumatism 2012; 64(7):2356-65. https://doi.org/10.1002/art.34410 PMid: 22294381

12. Yeh TT, Yang YH, Lin YT, Lu CS, Chiang BL. Cardiopulmonary involvement in paediatric systemic lupus erythematosus: a twenty-year retrospective analysis. Journal of Microbiology, Immunology and Infection 2007; 40(6):525-31.

PMid: 18087634

13. Cabral M, Escobar C, Conde M, Ramos M, Melo Gomes JA. Juvenile systemic lupus erythematosus in Portugal: clinical and immunological patterns of disease expression in a cohort of 56 patients. Acta Reumatologica Portuguesa 2013; 38(4):274-85.

PMid: 24435032

14. Srivastava P, Abujam B, Misra R, Lawrence A, Agarwal V, Agarwal A. Outcome of lupus nephritis in childhood onset SLE in North and Central India: single-centre experience over 25 years. Lupus. 2016; 25(5):547-57. https://doi.org/10.1177/096120331561903 1

PMid: 26637291

15. Ruggiero B1, Vivarelli M, Gianviti A, Benetti E, Peruzzi L, Barbano G, et al. Lupus nephritis in children and adolescents: results of the Italian Collaborative Study. Nephrology, Dialysis, Transplantation 2013; 28(6):1487-96. https://doi.org/10.1093/ndt/gfs589 PMid: 23345627 
16. Smet AD, Kuypers D, Evenepoel P, Maes B, Messiaen T, Van Damme B, et al. 'Full house' positive immune-histochemical membrano-proliferative

glomerulonephritis in a patient with portosystemic shunt. Nephrology, Dialysis, Transplantation 2001; 16(11): 2258-62. https://doi.org/10.1093/ndt/16.11.2258

17. Baskin E, Agras PI, Menekse N, Ozdemir $\mathrm{H}$, Cengiz N. Full-house nephropathy in a patient with negative serology for lupus. Rheumatology International 2007; 27(3): 281-4.

https://doi.org/10.1007/s00296-006-01980

PMid: 16972085

18. Gibson KL, Gipson DS, Massengill SA, Dooley MA, Primack WA, Ferris MA, et al. Predictors of relapse and end stage kidney disease in proliferative lupus nephritis: Focus on children, adolescents, and young adults. Clinical Journal of the American Society of Nephrology 2009; 4(12): 1962-7.

https://doi.org/10.2215/CJN.00490109

PMid: 19820130 PMCid: PMC2798882

19. Brugos B, Kiss E, Szodoray P, Szegedi G, Zeher M. Retrospective analysis of patients with lupus nephritis: Data from a large clinical immunological centre in Hungary. Scandinavian Journal of Immunology 2006; 64(4):433-7. https://doi.org/10.1111/j.13653083.2006.0 1833.x

PMid: 16970686

20. Costenbader KH, Desai A, Alarcon GS, Hiraki LT, Shaykevich T, Brookhart MA, et al. Trends in the incidence, demographics, and outcomes of end-stage renal disease due to lupus nephritis in the US from 1995 to 2006. Arthritis and Rheumatism 2011; 63(6):1681-8. https://doi.org/10.1002/art.30293 PMid: 21445962 PMCid: PMC3106117
21. Fiehn C, Hajjar Y, Mueller K, Waldherr R, Ho AD, Andrassy K. Improved clinical outcome of lupus nephritis during the past decade: importance of early diagnosis and treatment. Annals of the Rheumatic Diseases 2003; 62(5):435-9.

https://doi.org/10.1136/ard.62.5.435

PMid: 12695156 PMCid: PMC1754523

22. Hiraki LT, Benseler SM, Tyrrell PN, Hebert D, Harvey E, Silverman ED. Clinical and laboratory characteristics and long-term outcome of paediatric systemic lupus erythematosus: a longitudinal study. Journal of Pediatrics 2008; 152(4):550-6.

https://doi.org/10.1016/j.jpeds.2007.09.01 9

PMid: 18346514

23. Jurencak R, Fritzler M, Tyrrell P, Hiraki L, Benseler S, Silverman E. Autoantibodies in paediatric systemic lupus erythematosus: ethnic grouping, cluster analysis, and clinical correlations. Journal of Rheumatology 2009; 36(2):416-21. https://doi.org/10.3899/jrheum.080588 PMid: 19208567

24. Kasturi S, Sammaritano LR. Corticosteroids in lupus. Rheumatic Diseases Clinics of North America 2016; 42(1):47-62.

https://doi.org/10.1016/j.rdc.2015.08.007 PMid: 26611550

25. Thakral A, Klein-Gitelman MS. An update on treatment and management of paediatric systemic lupus erythematosus. Rheumatology and Therapy 2016; 3(2): 209-19. https://doi.org/10.1007/s40744-016-00440

PMid: 27747587 PMCid: PMC5127968 